\title{
Usability of Terrestrial Laser Technique in Forest Management Planning
}

\author{
Mücahit Emre Oruç*1®, İldeniz Leyla Öztürk $1 \oplus$ \\ ${ }^{1}$ Mersin University, Department of Remote Sensing \& GIS, Mersin, Turkey
}

\section{Keywords}

Forest management plan

TLS

Point cloud

3D model

\begin{abstract}
Studies in forestry in Turkey have great importance between humanity and life. In this direction, many forestry studies are carried out. The purpose of these studies is to protect forest areas and to ensure their continuity. The forestry organization continues to work urgently in line with this purpose. As a result of the researches, it is seen that old methods are lacking in time and cost in the forest management plan and many forestry studies. Nowadays, researches have been made on the use of the old methods, the use of terrestrial laser technology, which is seen as costly but actually offers positive opportunities at a low cost in line with the purpose to be used. In this study, how the methods used in forest management plans can contribute to the forestry sector with terrestrial laser scanning, which is one of today's technologies, and the sensitivity of devices and software that can be used in this direction are scrutinized. The data obtained as a result of the study were compared with the old methods and the usability of the terrestrial laser scanning method was examined.
\end{abstract}

\section{INTRODUCTION}

Forestry studies are activities that are carried out in a wide range of long-term and contain difficult conditions (Şafak \& Gül, 2012). There is an important need for information in the realization of these activities, which consist of planning, decision-making and management stages (Eker \& Özer, 2015; Buğday, 2016; Buğday, 2019).

Turkey has rich forest areas where the various types of wood. the importance given to forest areas in Turkey are progressing in the past with today's sustainable and innovation studies (Polat \& Kaya, 2021). As a result of research conducted in the presence of Forests Turkey, prepared a five year Global Forest Resources Assessment (FRA-Global Forest Resources Assessment) in 2020 according to the report; While it rises to 27 th place in the world ranking in the forest existence ranking, it is ranked 1st in Europe and 6th in the world among the countries that increase forest existence (URL-2; URL-3). forest assets in Turkey in the past 18 years, 2.1 million hectares have been increased. Turkey's 2023 target is visionary in forested areas are planned to correspond to $30 \%$ of my area of the country. The areal value of this ratio corresponds to approximately 23.4 million hectares. (URL1).

Forestry adversely affected to Turkey's contribution to the protection of forest ecosystems is needed in many areas. Forest management; It is a science that investigates how, when and in what criteria forests can be used and how to obtain more efficiency from forests in order to ensure continuity of forests (Kaplan \& Şeylan, 2007).

Referring to the historical development of forest management in Turkey when there is no regular continuity until 1857 . With the reform edict issued in 1856, many studies were carried out in many areas. When these studies were found, it was desired to benefit from forestry movements to contribute to the conditions. In order to ensure the continuity of developments in the field of forestry, schools for educational purposes were opened and the personnel to work in this field were technically trained. Important steps have been taken in the field of forestry by bringing foreign experts from other countries in order to enact the necessary legislation for the implementation of innovations (Eler, 2008). 
Despite all these steps taken; It is known that there are problems in determining forest boundaries, preserving, managing and transferring current forest assets to future generations, and in preparing forest management plans. In this context, studies to be carried out in forest areas are of utmost importance.Today, in parallel with the advancing technological developments in these studies, different and new methods have been used in addition to the classical methods from the past (Kaya \& Polat, 2021). Among these methods are Remote Sensing and Geographic Information Systems (GIS), photogrammetry and LIDAR (Light Detection and Ranging / Laser Imaging Detection and Ranging).

\subsection{Study Area}

As the study area, measurements were carried out in a forested area within the Mersin University Çiftlikköy campus.

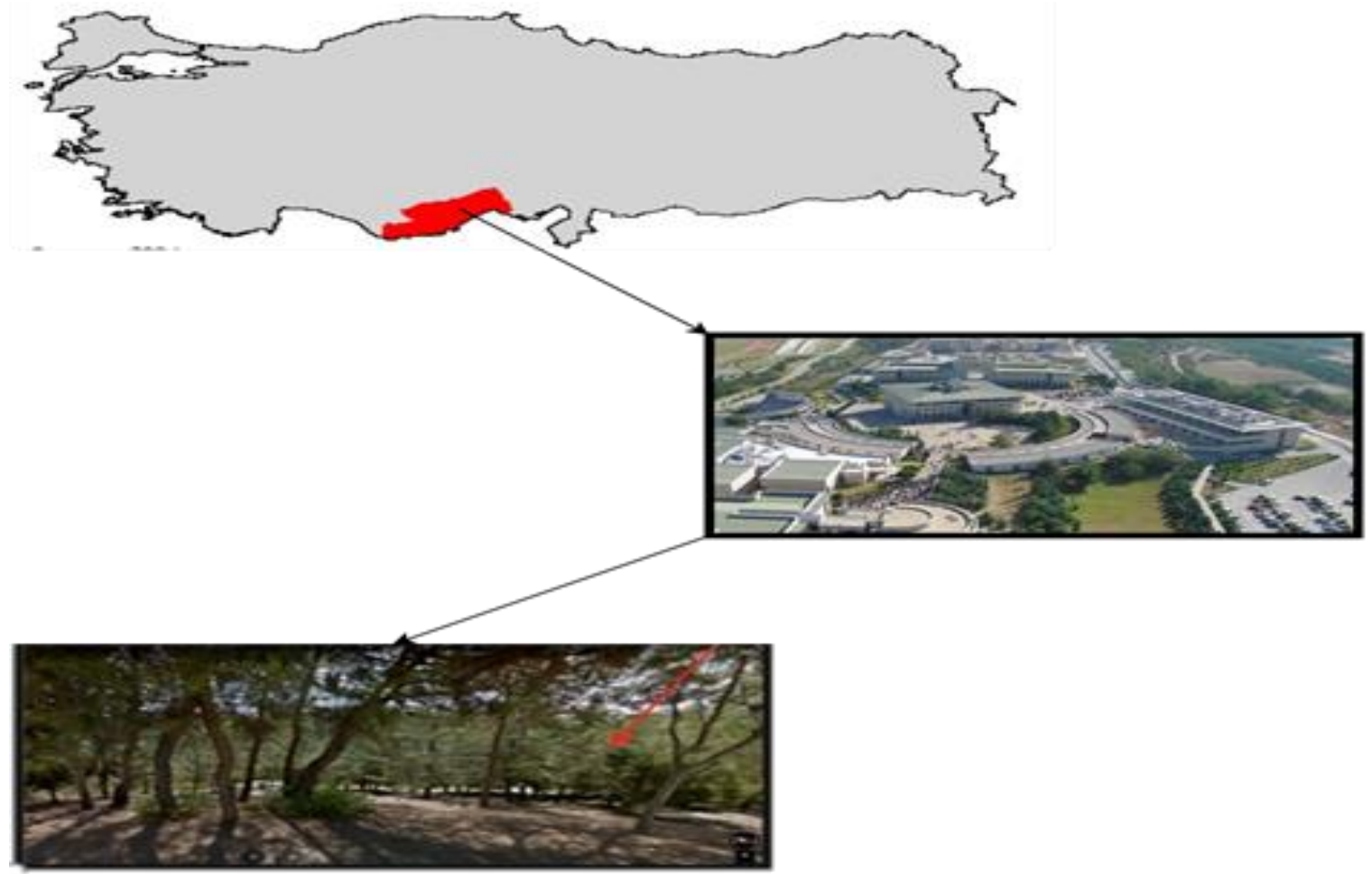

Figure 1. Study area

\section{MATERIAL and METHOD}

The terrestrial laser scanning (TLS) method was used in the study (Figure 2). With the laser beam emitted from the laser scanner device, the distance between the object and the device is measured. Thus, the point cloud of the scanning area can be obtained and three (3D) models of the desired object can be produced (Çelik et al., 2020; Ulvi et al., 2019). The distance between the laser scanning device and the object can be determined by means of the optical source, which is called the laser beam (Yakar et al., 2015). It has properties (monochromaticity, compatibility, divergence, reflection, density) that distinguish the laser beam from normal light. Thanks to these features, data about the shape and size of real objects can be easily collected and analyzed (Yakar et al., 2014; Ulvi et al., 2014). By means of mirrors, also known as laser optical scanning mechanism, the scanning of the object or the surface is performed by directing the laser beam in horizontal and vertical
The LIDAR method offers high resolution data regardless of the sparse and dense forest areas. In this context, a local laser scanner using LIDAR technology was used in the study area determined in the study, and the data belonging to the area were obtained precisely and quickly. By processing these data, the usability of the terrestrial laser scanner in forest areas was examined and the results were examined. 


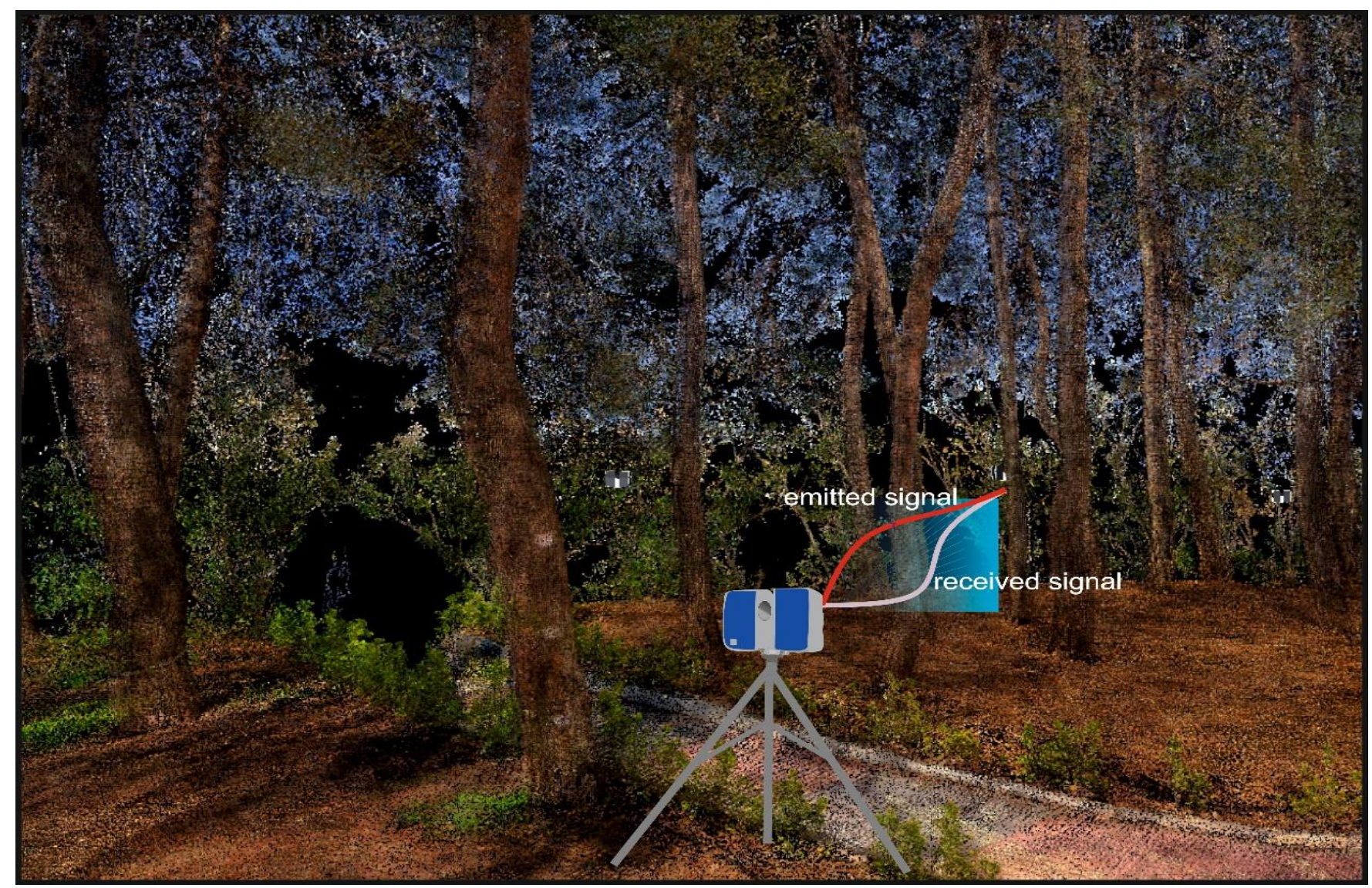

Figure 2. TLS method

In the TLS method, measurement can be performed from one point or several points with the terrestrial laser scanner. Although the measurements made from a single point are very practical, they are not preferred much in practice. Since scanning is performed from only one direction, it is highly possible that complete and healthy data regarding the scanned object cannot be obtained. Therefore, this application is not used except in compulsory cases. Instead, scanning is performed from more than one point (Senol et al., 2017; Senol et al., 2020). In this study, scanning was not carried out from a single point, the scans were carried out at more than one station point. Scan data has been processed in point cloud and a variety of commercial and open source software that enables 3D modeling.

\subsection{Data Collecting}

The determined working area was scanned with the local laser scanner Faro FocusS 350 model.

A forest area has been chosen as the study area. Testing the applicability of the ylt method played an important role in selecting such a field. As a result of the literature research, it has been determined that the predominant presence of pine trees in the forests in the Mediterranean region, the length of the trunk of these trees and therefore the tree branches will not prevent screening. Therefore, the application was carried out in the pine area located in the Mersin University Çiftlikköy

campus. The laser scanner was positioned to take the trunk parts of the trees from every angle with frequent sessions and the measurement process was completed in 11 sessions in total (Figure 3).

Table 1. Faro FocusS 350 specifications (Ceelik et al., 2020)

Scan Distance

Resolution

Quality

Measuring Speed

Internal straightness

Weight

Size
$0.6 m-350 m$

$1 / 1,1 / 2,1 / 4,1 / 5,1 / 8,1 / 10$, $1 / 16,1 / 20,1 / 32$

$2 x, 3 x, 4 x, 6 x$

$976.000 \mathrm{dot} / \mathrm{second}$

$\pm 1 \mathrm{~mm}$

$4,2 \mathrm{~kg}$

230x183x103mm

The perimeter of the tree trunk was measured from the reference points determined with the help of a rope by marking the reference points at 50,100,150 cm height of the tree trunks and the values were measured with the help of a steel tape measure (Figure 3, 4). 

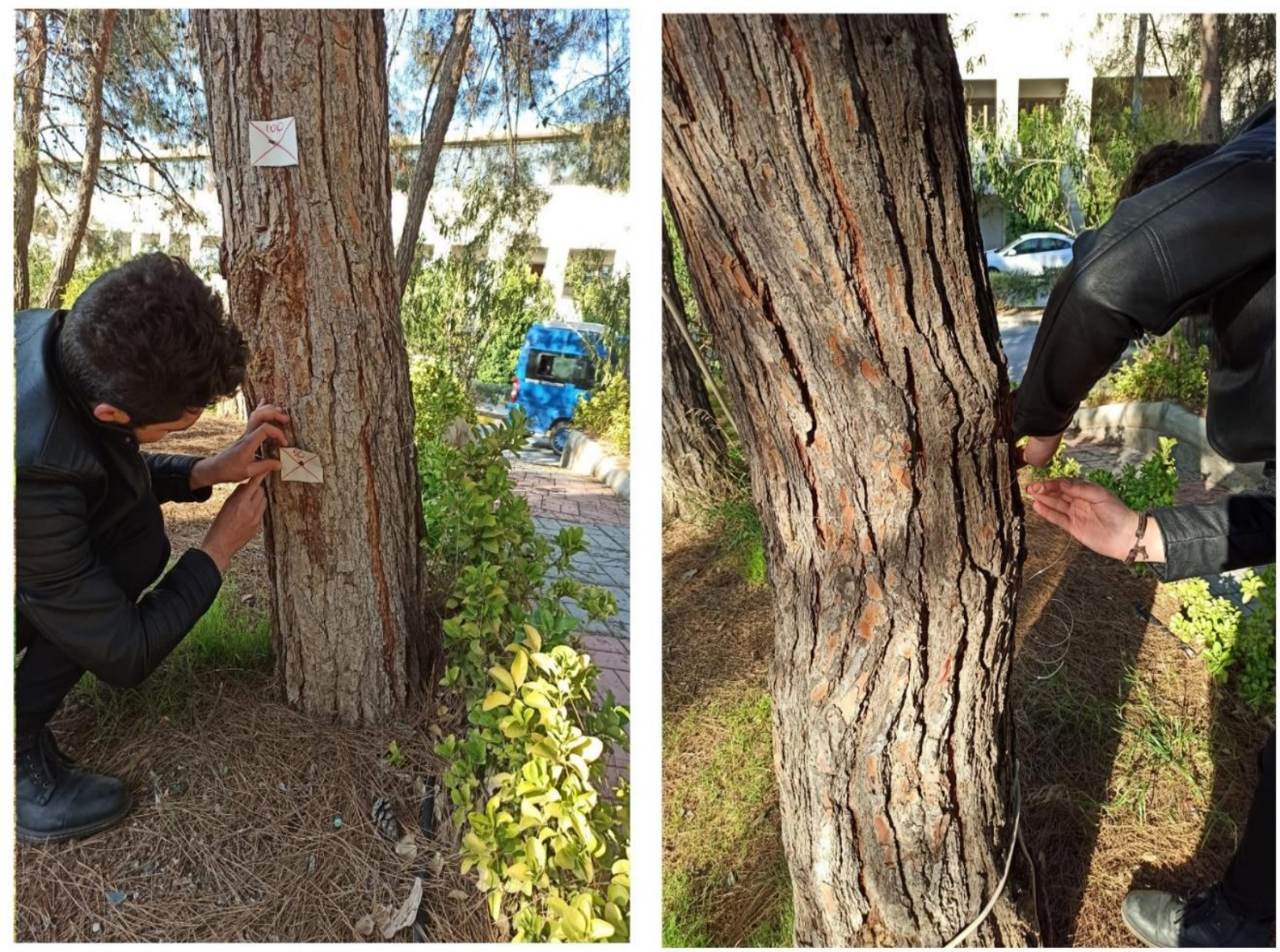

Figure 3. Fieldwork

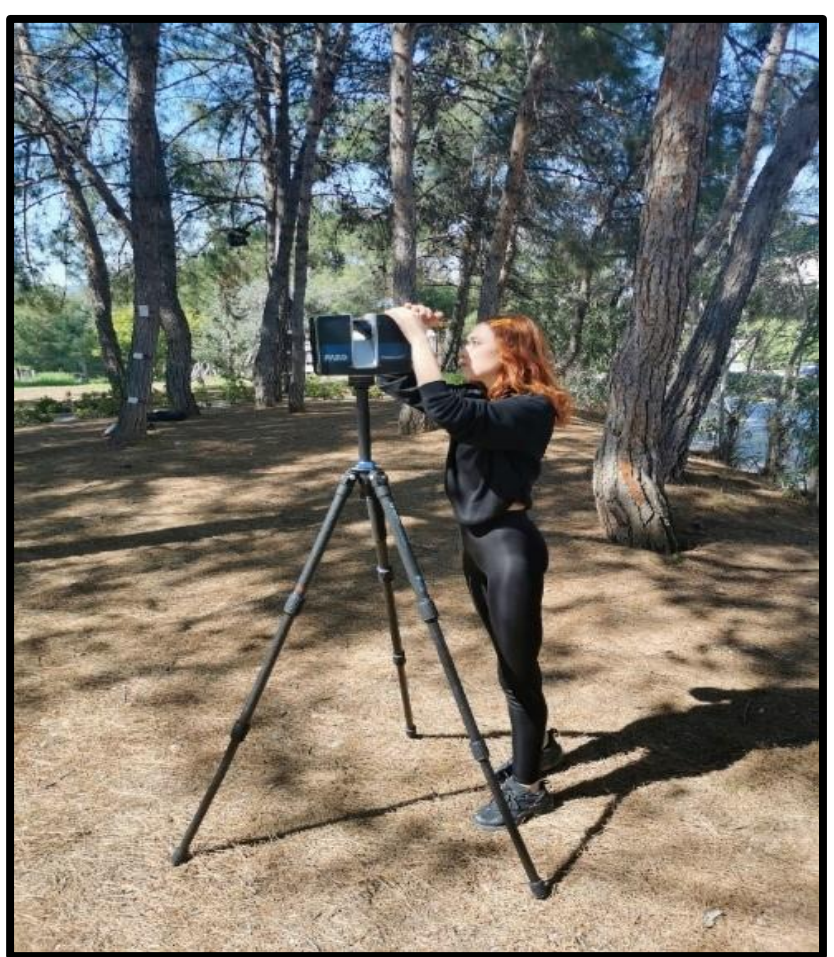

Figure 4. Scan samples performed in the study

\subsection{Data Processing}

The necessary data for processing the data were obtained by field measurements. FARO SCENE software, which is a commercial software, and various programs were used in the process of data processing. The scans made by processing the data in the software were combined. The point cloud of the study area was obtained as a result of the merging (Figure 5). A solid model was created through the obtained point cloud. Body circumferences and diameter values of the tree were measured on the 3D model. If desired, precise data can be obtained by coordinating the points with the TLS method and producing 3D models (Kaya et al., 2021; Yiğit \& Ulvi 2020).

Faro Scene software used for data processing has been developed to process scans obtained from all laser scanning devices. The software offers technical features such as automatic object recognition of objects found in scans, creating records in scans, and positioning.

After the scanning, the data were transferred to the software. First, the process process was applied. At this stage, the process of merging data with cloud to cloud point merging method has been completed. Considering the combined data, a simpler data was obtained by deleting the noise pollution data found in scans other than what was desired. This process is a noise removal process, and as a result of the process, it offers the user the opportunity to obtain a simpler and more usable data. After this step, the solid model (mesh) was created from the generated point cloud (Figure 6). In the product that emerged in the point cloud and solid model, the leaf parts of the trees combined with the sky, creating a confusion as green and blue color. However, this situation did not prevent our purpose. Because the volume calculation was made on the tree trunk parts. 


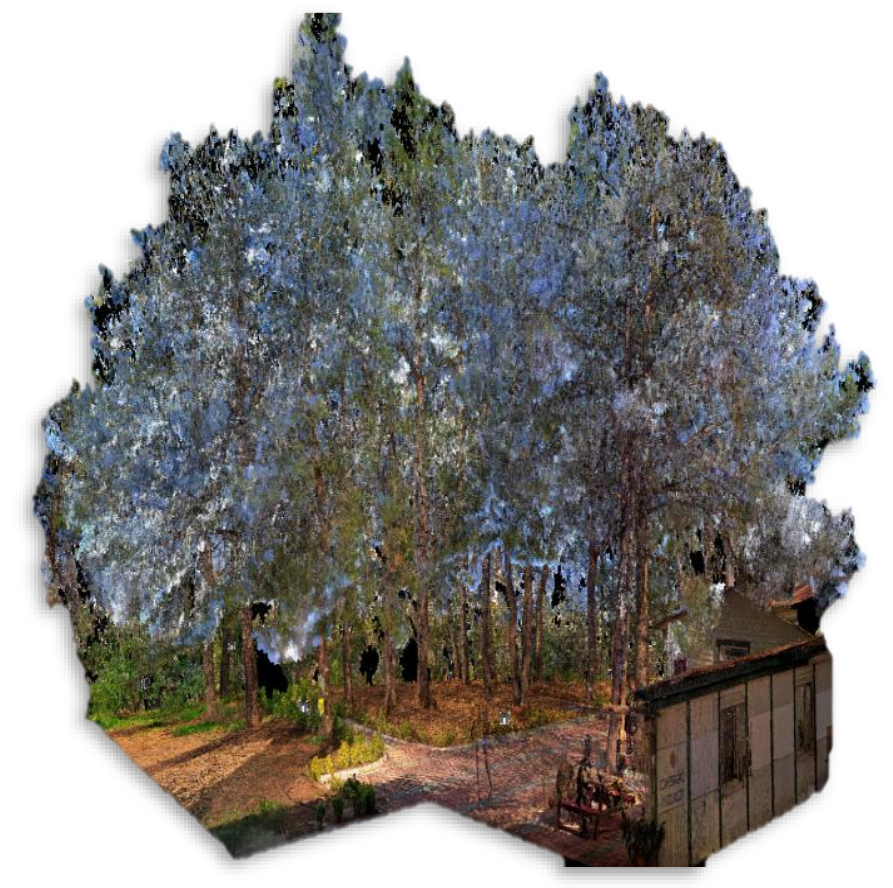

Figure 5. Point cloud view

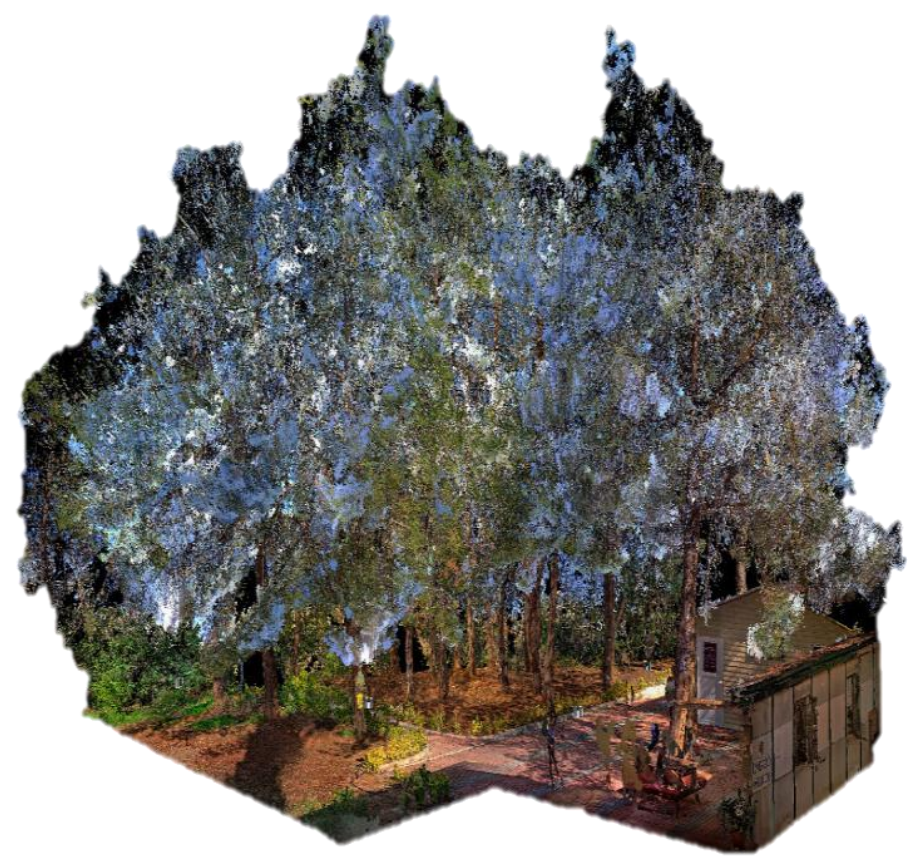

Figure 6. Solid model view

The data processed in Faro Scene software was exported in (.las) format and cut at the reference trunk heights of the determined trees and transferred to another software, Cloud Compare. This software allows many operations to be performed on point cloud data.
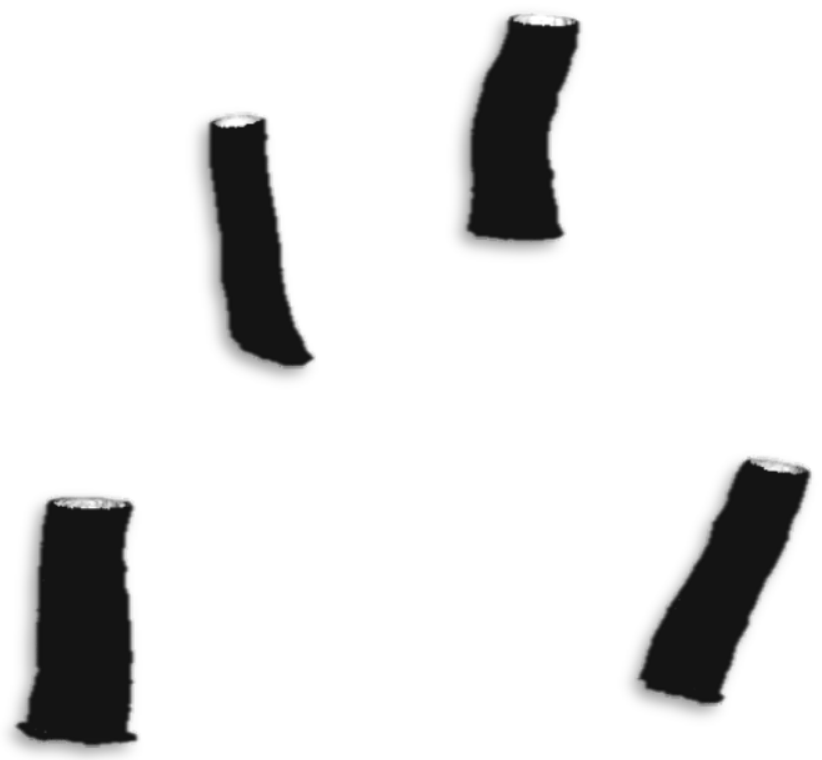

Figure 7. Point cloud data transferred to Cloud Compare software

In this software, the process of passing the tree trunks into the trees as a solid object through the software was applied (Figure 7, 8, 9). The volume calculations of the tree trunks were made by obtaining the cylinder radius and height information passed to the trunk parts. Then, the average diameter value was found according to the locally measured environmental measurements from the reference heights of the trees determined, and the volume calculation was made according to the huber measurement scale from the log volume calculation engine (Table 3 ).
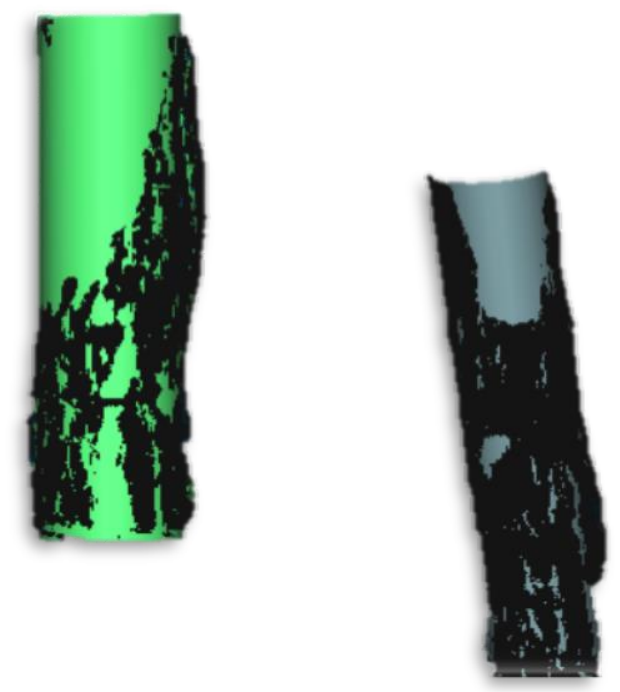

Figure 8. Cylinder views attached to tree trunks in cloud compare software 


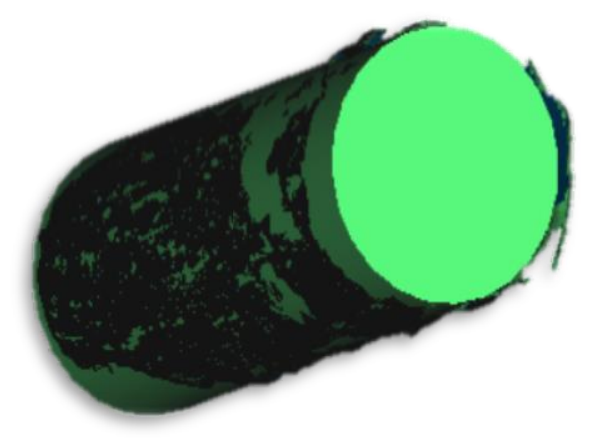

Figure 9. Cylinder views attached to tree trunks

In addition to the study, a volume calculation was made based on the locally obtained measurement values according to the volume calculation formula used in forestry. The sensitivity of the TLS method was examined by comparing the values found in this volume calculation with the volume calculations obtained by the TLS method. Volume calculation formula used in the study;

$$
\mathrm{V}=\frac{\pi}{4} \times \mathrm{r}^{2} \mathrm{xL}
$$

Here;

r: middle diameter value $(\mathrm{m})$,

L: length $(\mathrm{m})$

As a result of this formula, it is calculated gradually, together with the middle diameter value taken from the measured trees and certain height values(Table 4). In this study, volume calculations were made from the middle diameter values in accordance with the formula. The point cloud data obtained was exported and transferred to another software, Reconstructor software. The volume of the trunk of a tree for control purposes has been calculated.

\section{RESULTS}

In order to calculate the volume of the point cloud data obtained by the TLS method in the study, a cylinder was inserted into the trees in the Cloud Compare software according to the middle diameter value of the specified points. The volume calculations of these cylinders of known dimensions are made and the volume calculations of the values obtained by the spatial method are compared (Table 6). As a result of finding similar values in the volume calculations, it was seen that the TLS method can be used in similar studies like this.

As another method, another comparison factor was created by making the volume calculations obtained from the volume calculation formula, which is generally used in forestry studies (1). It has been observed that this formula is used locally in field measurements.
Table 2. Calculations obtained by spatial measurements

\begin{tabular}{ccccc}
\hline $\begin{array}{c}\text { Tree } \\
\text { number }\end{array}$ & $\begin{array}{c}\text { circumference } \\
\text { (cm) }\end{array}$ & $\begin{array}{c}\text { diameter } \\
\text { (cm) }\end{array}$ & $\begin{array}{c}\text { radius } \\
\text { (cm) }\end{array}$ & $\begin{array}{c}\text { height } \\
\text { (m) }\end{array}$ \\
\hline $\mathbf{1}$ & 124.5 & 39.65 & 19.82 & 1.50 \\
$\mathbf{2}$ & 73.2 & 23,31 & 11.65 & 1.50 \\
$\mathbf{3}$ & 99,1 & 31,56 & 15.78 & 1.50 \\
$\mathbf{4}$ & 104.6 & 33.31 & 16.66 & 1.50
\end{tabular}

Table 3. Volume calculation of spatial measurements with Huber method

\begin{tabular}{ccc}
\hline Medium Diameter & Length & Volume \\
\hline $\mathbf{3 9 . 6 5} \mathbf{~ c m}$ & $1.5 \mathrm{~m}$ & $0.19 \mathrm{~m}^{3}$ \\
$\mathbf{2 3 . 3 1} \mathbf{~ c m}$ & $1.5 \mathrm{~m}$ & $0.06 \mathrm{~m}^{3}$ \\
$\mathbf{3 1 . 5 6} \mathbf{~ c m}$ & $1.5 \mathrm{~m}$ & $0.12 \mathrm{~m}^{3}$ \\
$\mathbf{3 3 . 3 1} \mathbf{~ c m}$ & $1.5 \mathrm{~m}$ & $0.13 \mathrm{~m}^{3}$ \\
\hline
\end{tabular}

Table 4. Results obtained from the formula used to calculate the volumes of trees

\begin{tabular}{llcc}
\hline $\begin{array}{l}\text { Tree } \\
\text { number }\end{array}$ & $\begin{array}{l}\text { Medium } \\
\text { Diameter }\end{array}$ & Length & Volume \\
\hline $\mathbf{1}$ & $39.65 \mathrm{~cm}$ & $1.5 \mathrm{~m}$ & $0.1852 \mathrm{~m}^{3}$ \\
$\mathbf{2}$ & $23.31 \mathrm{~cm}$ & $1.5 \mathrm{~m}$ & $0.06 \mathrm{~m}^{3}$ \\
$\mathbf{3}$ & $31.56 \mathrm{~cm}$ & $1.5 \mathrm{~m}$ & $0.12 \mathrm{~m}^{3}$ \\
$\mathbf{4}$ & $33.31 \mathrm{~cm}$ & $1.5 \mathrm{~m}$ & $0.1307 \mathrm{~m}^{3}$ \\
\hline
\end{tabular}

Table 5. Volume calculations obtained by cylinder passing method in Cloud Compare software

\begin{tabular}{lcc}
\hline Medium Diameter & Length & Volume \\
\hline $\mathbf{3 9 . 0 6 4 6 ~ c m ~}$ & $1.5 \mathrm{~m}$ & $0.18 \mathrm{~m}^{3}$ \\
$\mathbf{2 1 . 9 6} \mathbf{~ c m}$ & $1.5 \mathrm{~m}$ & $0.06 \mathrm{~m}^{3}$ \\
$\mathbf{3 0 . 4 2} \mathbf{~ c m}$ & $1.5 \mathrm{~m}$ & $0.11 \mathrm{~m}^{3}$ \\
$\mathbf{3 4 . 4 3} \mathbf{~ c m}$ & $1.5 \mathrm{~m}$ & $0.14 \mathrm{~m}^{3}$ \\
\hline
\end{tabular}




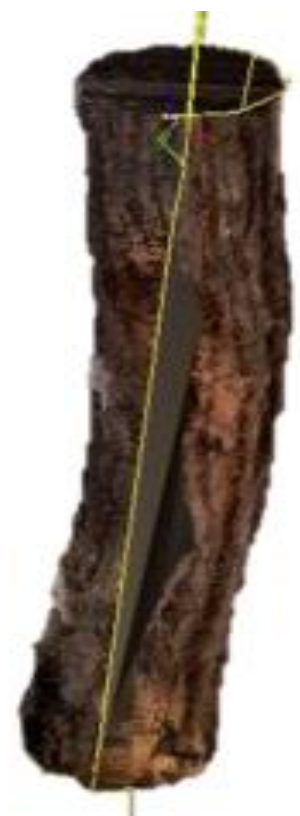

Figure 10. Volume value obtained in Reconstructor software (tree number: 1)

As a result of the volume calculation in the reconstructor software, an approximate result has been found for the volume values obtained from other spatial methods and software. This has been an indicator that reliable results can be obtained at the point of volume calculation made in the study. Likewise, the volume value of the tree numbered 1 was found to be $0.18 \mathrm{~m}^{3}$ in cloud compare software. In the Reconstructor software, it was found to be $0.1740 \mathrm{~m}^{3}$ (Figure 10). The volume calculation obtained in both software was found with a difference of $0.006 \mathrm{~m}^{3}$. Comparison was made for all methods used and volume calculations obtained, and other methods were examined according to the referenced method. The volume value for the tree numbered 1 was used as the comparison data.

Table 6. Comparison of number 1 tree volume among the methods used.

\begin{tabular}{lcc}
\hline Method used & Calculated volume & Reference \\
\hline Formula calculation & $0.1852 \mathrm{~m}^{3}$ & - \\
Huber method & $0.19 \mathrm{~m}^{3}$ & $0.0048 \mathrm{~m}^{3}$ \\
Cloud Compare & $0.18 \mathrm{~m}^{3}$ & $0.0052 \mathrm{~m}^{3}$ \\
Reconstructor & $0.1740 \mathrm{~m}^{3}$ & $0.0112 \mathrm{~m}^{3}$ \\
\hline
\end{tabular}

As a result of the comparison, the margin of error is very low. That is, the usability of the methods is stipulated. But when looking at the errors, the method with the lowest error was the Huber method calculated by the local method, and the volume value calculated with the cloud compare software from the data obtained by the TLS method.

\section{CONCLUSION}

In this study, since a forested area was preferred, the point cloud obtained was combined with high resolution and low error to obtain a point cloud and a solid model. However, it has been determined that a single software is not sufficient for software. On the other hand, since the surface shapes in the study area have various geometric shapes and the leaf regions in the upper parts of the tree are scattered and thin coniferous, a healthy data was not obtained in the point cloud. The sensitivity of the laser scanner used in this study was examined by comparing the measurements of the reference points marked on the body parts of the tree with a steel tape measure and the measurements made from the 3D solid model produced from the scans.

With the results obtained, error values were calculated and values very close to the results obtained by local methods were obtained. Since more area can be scanned in a short time in the TLS method and the volume calculations of trees will be calculated more easily with the software used, the usability of the ylt method is envisaged. With the TLS method, it provides a great advantage both in time and in the workforce of the measurements to be made in the field. However, today, the use of such methods due to different perceptions has not gained much place. Because this technique, which is considered to be too costly, can be more advantageous than local measurements in terms of cost. In terms of both precision and time saving, it was aimed to determine the forest existence and to show its usability sensitively in the studies to be done in this area. Since there is not a single tree in the field of forestry and forest management planning, it is predicted that such methods can be used technologically in many aspects.

\section{ACKNOWLEDGEMENT}

This study was presented as an oral presentation in the "The 2nd Intercontinental Geoinformation Days (IGD) 2021.

\section{REFERANCES}

Buğday E (2016), Ormancılıkta Üretimin Planlaması ve Hassas Ormancılık Anlayışı. Anadolu Orman Araştırmaları Dergisi, 2(1-2), 54-57.

Buğday E (2019), Orman yönetiminde insansız hava aracı uygulamaları. 2nd International Eurasian Conference on Biological and Chemical Sciences (EurasianBioChem 2019), June 28-29

Çelik M Ö, Hamal S N G \& Yakar İ (2020). Yersel Lazer Tarama (Ylt) Yönteminin Kültürel Mirasın Dokümantasyonunda Kullanımı: Alman Çeşmesi Örneği. Türkiye Lidar Dergisi, 2(1), 15-22.

Eker M \& Özer D (2015). Üretim işlerinde hassas ormancıllk yaklaşımı: Kavramsal çerçeve. Türkiye Ormancıllk Dergisi, 16(2), 183-194.

Kaplan S Y \& Şaylan (2007). G. T. D. Yerleşim Alanları Civarındaki Ormanların Yerinden Yönetimi Sorunu (Doctoral dissertation, Ankara Üniversitesi

Kaya Y \& Polat N (2021). Bitki İndeksleri Kullanarak Buğday Bitkisinin Rekolte Tahmini. Dicle Üniversitesi 
Mühendislik Fakültesi Mühendislik Dergisi, 12(1), 99110.

Kaya Y, Yiğit A Y, Ulvi A \& Yakar M (2021). Arkeolojik Alanların Dokümantasyonununda Fotogrametrik Tekniklerinin Doğruluklarının Karşılaştırmalı Analizi: Konya Yunuslar Örneği.Harita Dergisi, 165, 57-72.

Polat N \& Kaya Y (2021). Çok Bantlı Uydu Görüntüleriyle Orman Yangınlarında Hasar Tespiti. Bartın Orman Fakültesi Dergisi, 23 (1), 172-181.

Senol, H. I., Erdogan, S., Onal, M., Ulukavak, M., Memduhoglu, A., Mutlu, S., ... \& Yilmaz, M. (2017). 3D Modeling of A Bazaar in Ancient Harran City Using Laser Scanning Technique. International Archives of the Photogrammetry, Remote Sensing \& Spatial Information Sciences, 42.

Şafak İ \& Gül A U (2012), Orman mühendislerinin orman işlevlerine ve ormancılık faaliyetlerine verdikleri önem düzeylerinin değerlendirilmesi. SDÜ Orman Fakültesi Dergisi (13), 123-133.

Şenol, H. İ., Memduhoglu, A., \& Ulukavak, M. (2020). Multi instrumental documentation and 3D modelling of an archaeological site: a case study in Kizilkoyun Necropolis Area. Dicle Üniversitesi Mühendislik Fakültesi Mühendislik Dergisi, 11(3), 1241-1250.

Ulvi A, Yakar M, Toprak A S \& Mutluoglu O (2014). Laser Scanning and Photogrammetric Evaluation of Uzuncaburç Monumental Entrance. International Journal of Applied Mathematics Electronics and Computers, 3(1), 32-36.

Ulvi A, Yakar M, Yiğit A \& Kaya Y (2019). The Use of Photogrammetric Techniques in Documenting Cultural Heritage: The Example of Aksaray Selime Sultan Tomb. Universal Journal of Engineering Science, 7(3), 64-73.
Eler Ü (2008). Türkiye'de orman amenajman yönetmeliğinin tarihsel gelişimi. Türkiye Ormancılık Dergisi, 9(2), 89-98.

Yakar M, Kabadayı A, Yiğit A Y, Çıkıkcı K, Kaya Y \& Catin S S (2016). Emir Saltuk Kümbeti Fotogrametrik Rölöve Çalişmasi Ve 3Boyutlu Modellenmesi. Geomatik, 1(1), 14-18.

Yakar M, Ulvi A \& Toprak A S (2015). The Problems and Solution Offers, Faced During The 3d Modeling Process Of Sekiliyurt Underground Shelters With Terrestrial Laser Scanning Method. International Journal of Environment and Geoinformatics, 2(2), 3945.

Yakar M, Yilmaz H M \& Mutluoglu O (2014). Performance of Photogrammetric and Terrestrial Laser Scanning Methods in Volume Computing of Excavtion and Filling Areas. Arabian Journal for Science and Engineering, 39(1), 387-394.

Yiğit A Y \& Ulvi A (2020). İHA Fotogrametrisi Tekniği Kullanarak 3B Model Oluşturma: Yakutiye Medresesi Örneği. Türkiye Fotogrametri Dergisi, 2(2), 46-54.

URL-1:

https://www.ogm.gov.tr/tr/haberler/turkiyeorman-varligini-artiran-ulkeler-siralamasindaavrupa-da-1-inci-dunyada-ise-6-sirada

URL-2: http://www.fao.org/documents/card/en/c/ca925e n/

URL-3: http://www.gonder.org.tr/?p=9782 